\title{
Assessment of the metal pollution in surface sediments of coastal Tasaul Lake (Romania)
}

\author{
Dan Vasiliu (i) • Andra Bucse • Naliana Lupascu • \\ Bogdan Ispas • Catalin Gheablau • Ion Stanescu
}

Received: 11 July 2020 / Accepted: 20 October 2020 /Published online: 5 November 2020

(C) The Author(s) 2020

\begin{abstract}
Forty-three surface sediment samples were collected in September 2019 from Tasaul Lake (Black Sea coast, Romania) to examine the metal distribution patterns, assess the level of metal contamination, and identify the pollutant sources. The determined mean metal concentrations were as follows: $\mathrm{Al} \mathrm{49,772} \mathrm{mg/kg,}$ Zn $84.40 \mathrm{mg} / \mathrm{kg}$, Cr $83.70 \mathrm{mg} / \mathrm{kg}, \mathrm{V} 76.45 \mathrm{mg} / \mathrm{kg}$, Ni $42.53 \mathrm{mg} / \mathrm{kg}, \mathrm{Cu} 34.27 \mathrm{mg} / \mathrm{kg}, \mathrm{Pb} 26.30 \mathrm{mg} / \mathrm{kg}$, As $12.49 \mathrm{mg} / \mathrm{kg}$, and $\mathrm{Hg} 0.06 \mathrm{mg} / \mathrm{kg}$. The metals in the surface sediments of Tasaul Lake displayed moderate spatial variation, with higher metal concentrations mainly occurring in the south and southeast (As, $\mathrm{Pb}$, and $\mathrm{Hg}$ ), southwest $(\mathrm{Cu}$ and $\mathrm{Zn})$, and west of the lake $(\mathrm{Cr}, \mathrm{Ni}$, and $\mathrm{V})$. Heavy metal contamination in sediments is assessed using pollution indices such as enrichment factor, contamination factor, and pollution load index. The highest CFs and EFs were determined for As (moderate to high pollution), followed by $\mathrm{Pb}$ (low to moderate pollution). The $\mathrm{Cu}, \mathrm{Zn}$, and $\mathrm{Hg}$ pollution indices showed values corresponding to low pollution levels, while $\mathrm{Ni}, \mathrm{Cr}$, and $\mathrm{V}$ presented the lowest indices, suggesting unpolluted
\end{abstract}

D. Vasiliu $(\bowtie) \cdot$ A. Bucse $\cdot$ N. Lupascu $\cdot$ B. Ispas •

C. Gheablau · I. Stanescu

National Institute for Research and Development on Marine

Geology and Geoecology (GeoEcoMar), 23-25 Dimitrie Onciul, 024053 Bucharest, Romania

e-mail: dan.vasiliu@geoecomar.ro

A. Bucse

Chemical and Biochemical Engineering Department, University Politehnica of Bucharest, 1-3 Gheorghe Polizu, 011061 Bucharest, Romania sediments. Multivariate statistical analyses were performed to identify the origin of the analyzed heavy metals. Cr was predominantly sourced from lithogenic components, $\mathrm{Ni}$ and $\mathrm{V}$ originated from both natural and anthropogenic sources, and $\mathrm{As}, \mathrm{Cu}, \mathrm{Zn}, \mathrm{Pb}$, and $\mathrm{Hg}$ showed mainly anthropogenic sources such as agricultural runoff, domestic and industrial wastewater discharges, and quarrying activities.

Keywords Metals · Surface sediments · Tasaul Lake · Pollution indices $\cdot$ Coastal lakes

\section{Introduction}

Generally, coastal lakes are threatened ecosystems due to the numerous human activities carried out within their watersheds, resulting in multiple pressures (eutrophication, pollution, overfishing, etc.) that negatively impact ecosystem components and human health. Heavy metal pollution is one of the major pressures impacting lacustrine ecosystems owing to the toxicity, abundance, and persistence of heavy metals in the environment and their subsequent accumulation in the environment and organisms (Rippey et al. 2008; Atici et al. 2008; Varol 2011). Metals enter lakes from different sources, such as rock weathering, wind-borne soil particles, disposal of liquid effluents, terrestrial runoff carrying numerous chemicals resulting from urban, industrial, and agricultural activities, and atmospheric deposition (Jiang et al. 2012) and ultimately are 
deposited in sediments (Bing et al. 2011). Lake sediments act as either a permanent or temporary sink of metals; thus, their level of contamination provides an overall picture of health status of the lake ecosystem.

There are many coastal lakes along the Romanian Black Sea littoral region, some of them (those located in the south) strongly impacted by human activities (tourism, agriculture, industry, urban extension, etc.). The second largest lake in the Romanian littoral region is Tasaul Lake, located in the central part of the Romanian coast, south of the Danube Delta Biosphere Reserve. Its importance at regional scale results from the ecosystem services offered, particularly provisioning (fishery and water for agriculture purposes) and cultural (recreational and aesthetics).

Although its catchment area is not very densely populated, the human-induced pressures are quite significant, resulting mainly from agriculture, mining activities, and the petrochemical industry (Vasiliu et al. 2007). Studies on the impact of the anthopogenic pressures on Tasaul Lake ecosystem and the services provided are scarce and not readily accessible. The most recent studies were carried out within the framework of the project Assessment of anthropogenic impacts on Tasaul Lake, Romania and ecosystem rehabilitation (Swiss-Romanian cooperative program on "Environmental Science and Technology in Romania-ESTROM") from 2005 to 2008. They were mainly focused on fishery, eutrophication, primary productivity, etc. (Alexandrov et al. 2008; Cernisencu et al. 2007; Vasiliu et al. 2007; Rosioru et al. 2008), and to a lesser extent on the pollution assessment (Oros 2007; Bloesch and Alexandrov 2007). Oros (2007) showed good to moderate water quality and moderate sediment quality with respect to heavy metal contamination, but the actual contamination level as well as the origin of the pollution was not approached.

In this regard, the authors of the current study aim to quantify the anthropogenic influences on the metal contamination level in Tasaul Lake by using some pollution indices. Furthermore, the authors use multivariate statistical techniques for identifying the sources of metal enrichment and highlighting the most polluted sites in the lake, thus providing valuable information for management decisions aiming at improving the quality of Tasaul ecosystem services.

\section{Materials and methods}

Study area

Tasaul Lake (ca. $20 \mathrm{~km}$ north of Constanta, the most important city of the Dobrudja region) is a maritime liman, formed as an extension of the Casimcea River valley and separated from the Black Sea by a coastal bar (Popescu and Caraivan 2002-2003). It has an elongated and slightly meandering shape owing to alternating promontories and relatively large gulfs (Breier 1976). Its shores are mostly high (3-12 m), composed of Jurassic limestone in the northern part and green schist in the southern part (Breier 1976).

The lake has an area of ca. 2025 ha (Cernisencu et al. 2007) and a mean depth of $2.4 \mathrm{~m}$ (maximum depth of $3.75 \mathrm{~m}$ ), according to Breier (1976). There are two islands on the lake: Ada Island, with an area of 30.3 ha, and La Ostrov Island, with an area of 3 ha (Breier 1976) (Fig. 1).

South of the lake is Navodari (Fig. 1), an important city in the region due to industrial and, recently, touristic activities. The most important industrial facility is the petrochemical plant, to the east of the lake, a potential source of contaminants, mainly through its emissions. Other potential pollution sources linked to Navodari are domestic wastewater, waste disposal, and road traffic.

Apart from Navodari, there are three small villages around the lake: Piatra, located in the northwest, Sibioara, in the west, and Luminita, in the east (Fig. 1). The main human activities around these villages are mining and agriculture. Near each of the abovementioned villages, there are limestone (Piatra and Luminita) and greenschist (Sibioara) quarries, which can be seen as potential sources of metal pollution through quarry dust, which may harbor quite high levels of metals; leaching of metals from waste rock dumps; heavy car traffic, etc. (Tiimub et al. 2015). Other human activities carried out near these villages that might impact Tasaul Lake are animal husbandry (Sibioara), a feed factory (north of Sibioara), and port activities (Luminita port, located on the branch of the Poarta Alba-Midia Navodari Canal, which goes along the eastern lake border).

The northwestern part of the lake has been subject to hydrotechnical works aimed at developing fishing activities (there is a large fishing farm next to the mouth of the Casimcea River) (Alexandrov et al. 2008; Alexandrov and Bloesch 2009). The Casimcea River (mean flow of $0.22 \mathrm{~m}^{3} / \mathrm{s}$ ), the main tributary of Tasaul 


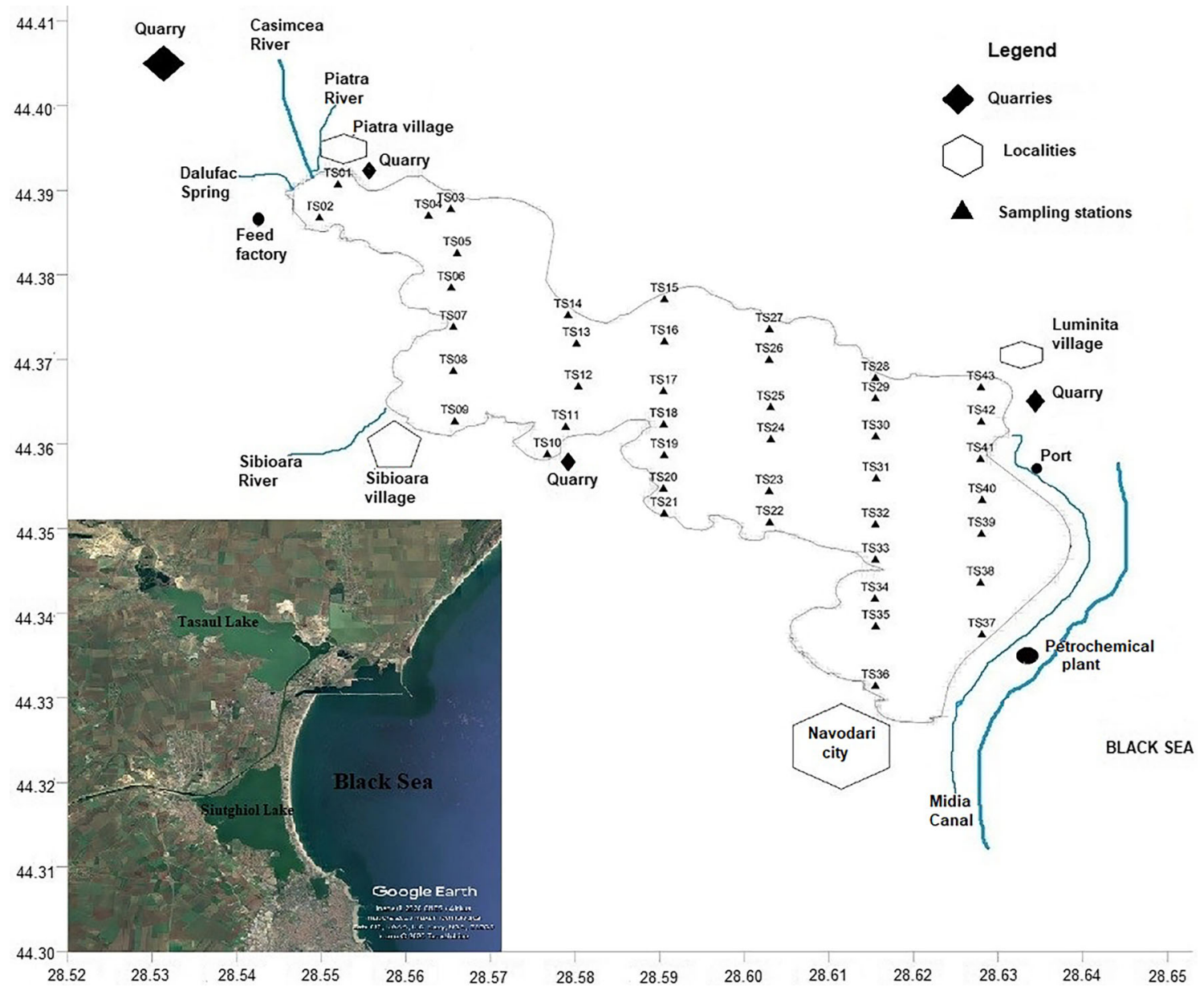

Fig. 1 Location of the study area and sampling sites

Lake with a relatively large catchment area $\left(830 \mathrm{~km}^{2}\right)$ (Mateescu et al. 2007), has been subject to hydrotechnical works upstream, which modified the flow patterns and consequently the suspended solids, nutrients, and contaminants discharged into the lake (Mateescu et al. 2007). Other tributaries are two small rivers, the Piatra and the Sibioara, and the Dalufac spring (Mateescu et al. 2007), which enter the lake in northwest, south, and west, respectively (Fig. 1).

Sampling and analytical procedures

The sampling program was carried out in September 2019 onboard the motorboat Carina. A total of 43 sediment samples were collected using a Van Veen grab $1000 \mathrm{~cm}^{2}$ (manufactured by KC Denmark). The $2-\mathrm{cm}-$ deep surface sediment was sliced for each sediment sample. The subsamples were stored in plastic bags and kept at $0-4{ }^{\circ} \mathrm{C}$ until subsequent analyses.

The grain size of the sediments was determined with a Mastersizer 2000 laser diffraction granulometer (Mastersizer 2000E, ver. 5.20) and associated dispersion units (Malvern Instruments, UK) with a measurement precision of $1 \%$ and result reproducibility below $1 \%$. The granulometric fractions are in accordance with the Udden-Wentworth dimensional scale with sand/silt and silt/clay boundaries of $63 \mu \mathrm{m}$ and $4 \mu \mathrm{m}$, respectively. The Shepard ternary diagram was used for lithological classification of sediment samples (Sheppard 1954).

Before geochemical analyses, the sediments were oven dried (24-48 h/105 $\left.{ }^{\circ} \mathrm{C}\right)$, ground, and homogenized with a mortar and pestle. The total organic carbon (TOC) concentrations were determined by the WakleyBlack titration method modified by Gaudette et al. (1974). The concentrations of $\mathrm{Al}, \mathrm{Cr}, \mathrm{Cu}, \mathrm{Ni}, \mathrm{Zn}, \mathrm{As}$, 
$\mathrm{V}$, and $\mathrm{Pb}$ were measured by $\mathrm{X}$-ray fluorescence spectrometry using an EDXRF Spectro Xepos spectrometer with a Pd/Co tube and XRF AnalyzerPro software (v. 3.3.2). A Direct Mercury Analyzer (DMA 80 Milestone, Italy) was used for the analysis of $\mathrm{Hg}$ in sediment samples. This instrument is based on drying sample and thermal decomposition, followed by electrothermal atomization of mercury. To validate the analytical methodology, a certified reference material (NCS DC 73022) was used. The measured and certified values of element/ compound concentrations were compared (Table 1). All of the results obtained for this reference material were statistically similar to the certified values $(p<0.05)$, demonstrating the reliability of the methodology and the estimated concentrations. The relative standard deviations of the measured replicates were all within $\pm 5 \%$.

\section{Pollution indices}

The level of sediment pollution in Tasaul Lake was assessed based on several indices, i.e., the enrichment factor $(\mathrm{EF})$, contamination factor $(\mathrm{CF})$, and pollution load index (PLI).

$\mathrm{EF}$ is widely used to separate natural variations in metals of from the metal fraction that is associated with sediments due to anthropogenic activities. The EF for each element was calculated to assess the actual contamination level (Sakan et al. 2009) using the following formula:

$\mathrm{EF}=\mathrm{EF}_{i}=\frac{C_{i, s} c_{\mathrm{ref}, b}}{C_{i, b} c_{\mathrm{ref}, s}}$

EF values were interpreted as suggested by AcevedoFigueroa et al. (2006), where EF $<1$ indicates no enrichment, $<3$ is minor, $3-5$ is moderate, $5-10$ is moderately severe, $10-25$ is severe, $25-50$ is very severe, and $>50$ is extremely severe.

$\mathrm{CF}$ is the ratio obtained by dividing the concentration of each metal in the sediment by the background value (concentration in uncontaminated sediment), according to the following formula:

$\mathrm{CF}=\mathrm{CF}_{i}=\frac{C_{i, s}}{C_{i, b}}$

$\mathrm{CF}$ values were interpreted as suggested by Hakanson (1980), where CF $<1$ indicates low contamination, $1<\mathrm{CF}<3$ is moderate contamination, 3 $<\mathrm{CF}<6$ is considerable contamination, and $\mathrm{CF}>6$ is very high contamination.
For the entire studied area, PLI was determined as the $n$th root of the product of $n \mathrm{CFs}$, according to the formula below:

$\mathrm{PLI}=\sqrt[n]{(\mathrm{CF} 1 \times \mathrm{CF} 2 \times \mathrm{CF} 3 \times \ldots \times \mathrm{CFn}}$

This empirical index provides a simple, comparative means for assessing the level of heavy metal pollution. PLI $>1$ suggests that pollution exists; PLI $<1$ means that there is no metal pollution (Tomlinson et al. 1980).

$C_{i, s}$ is the concentration of metal $i$ in the sample, and $c_{i, b}$ is the background concentration of metal $i$. Since no background data for metals in uncontaminated sediments in the study area are available, the concentration of metal $i, C_{i, b}$ $(\mathrm{mg} / \mathrm{kg}$ dry matter), in the surface sediments of upper continental crust (UCC) reported by Rudnic and Gao (2003) was used as a background value (i.e., $\mathrm{c}_{A l, b}=$ $81,500 \mathrm{mg} / \mathrm{kg}, c_{A s, b}=4.8 \mathrm{mg} / \mathrm{kg}, c_{P b, b}=17 \mathrm{mg} / \mathrm{kg}, c_{C u, b}$ $=28 \mathrm{mg} / \mathrm{kg}, c_{H g, b}=0.05 \mathrm{mg} / \mathrm{kg}, c_{N i, b}=47 \mathrm{mg} / \mathrm{kg}, c_{C r, b}=$ $92 \mathrm{mg} / \mathrm{kg}, c_{V, b}=97 \mathrm{mg} / \mathrm{kg}$, and $c_{Z n, b}=67 \mathrm{mg} / \mathrm{kg}$ ). $\mathrm{C}_{r e f s}$ and $\mathrm{C}_{\text {ref,b }}$ are the concentrations of reference elements in the samples and in surface sediments of UCC (Rudnic and Gao 2003). In this study, $\mathrm{Al}$ was chosen to normalize the elements due to its high natural abundance in the UCC. It is one of the most conservative metals, and is not affected by anthropogenic activities (Schropp et al. 1990; Liaghati et al. 2003).

Data processing

xlSTAT 7.5.2. Software (AddinSoft 2020) was used for statistical analyses. Multivariate statistical techniques, which included Pearson correlation and principal component analysis (PCA), were applied to investigate the potential sources of heavy metals in the sediments. Correlation analysis presents a statistical characterization of a quantitative variable by other quantitative variables to depict their relationships using the correlation coefficient (Pearson). PCA was performed on the metal concentration in sediment samples to further understand the grouping of heavy metals from the same source. The validity of PCA was evaluated by applying the Kaiser-Meyr-Olkin test and Bartlett's test. The principal components (PCs) with eigenvalues greater than one were considered to be relevant (Yang et al. 2014). To consider the contribution of elements to a given group, the components with factor loadings of $>0.6$, $0.4-0.6$, and $0.3-0.4$ were classified as highly, 
Table 1 Measured and certified values of standard material NCS DC 73022

\begin{tabular}{llll}
\hline Element & Measured value $(\mathrm{mg} / \mathrm{kg}) \pm \mathrm{SD}$ & Certified value $(\mathrm{mg} / \mathrm{kg}) \pm \mathrm{SD}$ & Recovery $(\%)$ \\
\hline $\mathrm{Cr}$ & $75 \pm 2.46$ & $72 \pm 3$ & 104 \\
$\mathrm{Al}_{2} \mathrm{O}_{3}$ & $12.88 \pm 0.31$ & $13.61 \pm 0.12$ & 94.6 \\
$\mathrm{As}$ & $289 \pm 2$ & $\mathbf{3 0 4} \pm \mathbf{2 0}$ & $\mathbf{9 5}$ \\
$\mathrm{Ni}$ & $32.2 \pm 0.12$ & $29 \pm 1$ & 110 \\
$\mathrm{Cu}$ & $503 \pm 4.58$ & $483 \pm 20$ & 104 \\
$\mathrm{~Pb}$ & $140.3 \pm 1.53$ & $126 \pm 5$ & 111 \\
$\mathrm{~V}$ & $100.1 \pm 0.81$ & $101 \pm 3$ & 99 \\
$\mathrm{Zn}$ & $861 \pm 11.79$ & $874 \pm 19$ & 98.5 \\
$\mathrm{Hg}$ & $0.122 \pm 0.005$ & $0.115 \pm 0.023$ & 106 \\
\hline
\end{tabular}

moderately, or weakly associated with elements in that class, respectively. Similar classification procedures have been used in similar studies focusing on the identification of heavy metal sources in sediments (Wu et al. 2014; Javed et al. 2018; Maina et al. 2019).

Agglomerative hierarchical clustering (AHC) analyses were carried out by using Ward's method (Ward 1963), with the Euclidean distance (proximity matrix) as a measure of dissimilarity to assess the associations among the sampling sites with respect to the pollution indices. AHC is an iterative classification method that initiates clustering by calculating the dissimilarity between different groups of objects and then clusters the objects together to minimize a given agglomeration criterion (Benson et al. 2016).

Surfer® (Golden Software, LLC) was used to map the spatial distribution of variables (grain size, TOC, heavy metals, and PLI) in the study area.

\section{Results and discussion}

Particle size and TOC

Generally, the study area is covered by clayey silt ( $40 \%$ of samples), mostly in the western part, and sandy silt (56\% of samples), except for two sampling stations located in the vicinity of Ada Island (TS29 and TS30), where the coarse fraction (sand + gravel) represents $>80 \%$ (Fig. 2). The silt fraction varied from $9.2 \%$ (station TS29) to $79.9 \%$ (stations TS01 and TS02), with an average of $69.7 \pm 14.1 \%$. The highest percentages of clay $(>20 \%)$ were found in the western part of the study area (stations TS02, TS03, TS04, TS05, TS06, and TS11), where the main tributary, the
Casimcea River, enters the lake, while the lowest percentage was determined at station TS29 (1.15\%).

The TOC concentrations in the surface sediments fluctuated from 0.29 to $3.73 \%$, with an average of 2.74 $\pm 0.86 \%$ (Table 2). The lowest TOC was recorded near Ada Island (station TS30), while the highest TOC was measured in the eastern part of the lake (maximum at station TS38) (Fig. 2). However, the TOC concentrations were relatively high, with values $>2 \%$ being measured in $63 \%$ of samples. The TOC values showed significant negative correlations with sand and gravel fractions and positive correlations with silt and clay fractions (Table 3).

\section{Metal concentrations and spatial distribution}

The mean values of metal concentrations showed a decreasing order: $\mathrm{Al} \gg>>\mathrm{Zn}>\mathrm{Cr}>\mathrm{V}>\mathrm{Ni}>\mathrm{Cu}>\mathrm{Pb}>\mathrm{As}>$ $\mathrm{Hg}$. The minima, maxima, means, standard deviations, and coefficients of variation $(\mathrm{CV}, \%)$ for each studied metal and TOC $(n=43)$ are presented in Table 2.

Metal concentrations in the surface sediments presented low to moderate spatial variability, with $\mathrm{CVs}$ ranging from 8.3 to $38.4 \%$ (minimum for $\mathrm{Cr}$ and maximum for $\mathrm{Hg}$ ) (Table 2). $\mathrm{Al}, \mathrm{Cr}, \mathrm{Ni}$, and $\mathrm{V}$ showed quite similar distributions, with the highest concentrations in the northern part of the lake ( $\mathrm{Al}$ and $\mathrm{Cr}$ at station $\mathrm{TS} 07$ and $\mathrm{Ni}$ and $\mathrm{V}$ at station TS05) (Fig. 3). $\mathrm{Cu}$ and $\mathrm{Zn}$ showed maxima at station TS10, while the highest concentrations of $\mathrm{As}, \mathrm{Pb}$, and $\mathrm{Hg}$ were measured in the southeastern part of the lake (stations TS32, TS33, and TS35, respectively) (Fig. 3). The lowest concentrations were found at stations $\mathrm{TS} 01(\mathrm{Ni}, \mathrm{Cu}, \mathrm{Zn}, \mathrm{V}$, and $\mathrm{Pb})$, TS21 (As and Hg), TS29 (Cr), and TS34 (Al) (Fig. 3). 




Fig. 2 Grain size and TOC in the surface sediments of Tasaul Lake

Romanian coastal lakes, particularly Tasaul Lake, have been quite poorly investigated in terms of sediment quality (Oros 2007; Bloesch and Alexandrov 2007); thus, it is quite difficult to assess the temporal variability in heavy metals in sediments. However, by comparing our data with those collected by Oros (2007) in Tasaul Lake (the only available study), it can be remarked that quite similar $\mathrm{Cu}$ concentrations and significantly lower $\mathrm{Pb}$ and $\mathrm{Ni}$ levels were measured in 2019. Regarding the spatial distribution, the current data showed similar patterns of $\mathrm{Ni}$ and $\mathrm{Pb}$ for both periods (higher Ni concentrations in the west of lake and higher $\mathrm{Pb}$ concentrations in east of the lake). $\mathrm{Cu}$ showed some differences in its spatial distribution; in 2019, higher concentrations were measured in the west, contrary to 2005-2007, when higher concentrations were observed in the east.

The heavy metal concentrations measured in this study were also compared with data collected from two other shallow coastal lakes (Tabacarie and Siutghiol), also located in the Constanta area, south of Tasaul Lake, as well as some coastal lakes from other countries (Table 4).

Data reported by Caraivan et al. (2011) and Bucur Arpenti et al. (2014) for Tabacarie and Siutghiol Lakes showed much higher concentrations for $\mathrm{Cu}, \mathrm{Ni}, \mathrm{Zn}$, and $\mathrm{Pb}$ (Tabacarie Lake) and $\mathrm{Hg}, \mathrm{Zn}$, and $\mathrm{Pb}$ (Siutghiol Lake), respectively (Table 4). These findings are in line with the pressures exerted by recreational activities, tourism, untreated/poorly treated domestic wastewater, and urban extension (Siutghiol), which are much stronger at these other lakes than in Tasaul Lake.

The heavy metal concentrations measured in other coastal lakes generally did not show significant differences compared with those found in the current study in Tasaul Lake (Table 4). Generally, the results show that the heavy metal concentrations in the study area fall within the range of those of other regions listed in the Table 4.

Heavy metal contamination sources

Potential sources of the measured heavy metals were identified by using Pearson correlations and PCA. Pearson's correlation coefficients for metals, TOC, and grain size in the surface sediments of Tasaul Lake are presented in Table 3.

TOC and particle size are two important factors in the distribution of metals in sediments (Aloupi and Angelidis 2001; Dou et al. 2013). The correlation matrix (Table 3) showed significant positive relationships between TOC and all heavy metals, except for $\mathrm{Cr}$, suggesting the major role played by organic matter in the transport processes of these metals (Kükrer et al. 2020). The significant positive correlations among $\mathrm{Cu}, \mathrm{Zn}, \mathrm{As}$, $\mathrm{Pb}$, and $\mathrm{Hg}$ might indicate that they originate from the

Table 2 Descriptive statistics for the studied variables (TOC, Al, and heavy metals)

\begin{tabular}{lllllllllll}
\hline & $\mathrm{TOC}(\%)$ & $\mathrm{Al}(\mathrm{mg} / \mathrm{kg})$ & $\mathrm{Cr}(\mathrm{mg} / \mathrm{kg})$ & $\mathrm{Ni}(\mathrm{mg} / \mathrm{kg})$ & $\mathrm{Cu}(\mathrm{mg} / \mathrm{kg})$ & $\mathrm{Zn}(\mathrm{mg} / \mathrm{kg})$ & $\mathrm{As}(\mathrm{mg} / \mathrm{kg})$ & $\mathrm{V}(\mathrm{mg} / \mathrm{kg})$ & $\mathrm{Pb}(\mathrm{mg} / \mathrm{kg})$ & $\mathrm{Hg}(\mathrm{mg} / \mathrm{kg})$ \\
\hline Min. & 0.29 & 41,506 & 72.3 & 27.74 & 15.12 & 46.4 & 5.86 & 54.40 & 16.50 & 0.02 \\
Max & 3.73 & 67,871 & 103.0 & 57.60 & 83.50 & 133.0 & 17.70 & 95.90 & 34.46 & 0.14 \\
Mean & 2.47 & 49,772 & 83.70 & 42.53 & 34.27 & 84.40 & 12.49 & 76.45 & 26.30 & 0.06 \\
SD & 0.86 & 4529 & 7.0 & 6.45 & 11.18 & 16.1 & 2.99 & 9.06 & 4.71 & 0.02 \\
$\mathrm{CV}(\%)$ & 34.8 & 9.1 & 8.3 & 15.2 & 32.6 & 19.1 & 23.9 & 11.8 & 17.9 & 38.4 \\
\hline
\end{tabular}


same sources and have similar transformation and migration processes (Wang et al. 2012). Ni and V showed a significant positive correlation with each other but also with $\mathrm{Cu}, \mathrm{Zn} \mathrm{As}$, and $\mathrm{Pb}$ (Table 3).

Generally, the heavy metal concentrations in the surface sediments increased with decreasing grain size (O'Reilly-Wiese et al. 1995). Nevertheless, among the heavy metals, only $\mathrm{Cr}, \mathrm{V}$, and $\mathrm{Ni}$ showed a significant positive correlation with the clay fraction, which might suggest lithogenic sources for those metals (Dou et al. 2013). As a major component of clayey minerals, Al was positively correlated with the clay fraction, but it showed significant positive correlations with $\mathrm{Cr}, \mathrm{Ni}$, and $\mathrm{V}$ as well, thus suggesting a natural origin for these heavy metals.

The PCA results showed three principal components with eigenvalues $>1$, accounting for approximately $85 \%$ of the total variance (Table 5). The first principal component (PC1), accounting for $46.9 \%$ of the total variance, was categorized by high positive loadings of TOC (0.649), Ni (0.819), Cu (0.757), Zn (0.880), As (0.823), $\mathrm{V}(0.781)$, and $\mathrm{Pb}$ (0.931). The abovementioned heavy metals represent the pollution group and are significantly associated with each other. The positive loading of $\mathrm{Hg}$ (0.598) was very close to 0.6 ; thus, this metal might be considered to be significantly associated with the abovementioned elements. The high loading factors indicated mainly anthropogenic sources of pollution.

PC2 accounted for $25.1 \%$ of the total variance (Table 5) and was dominated by $\mathrm{Al}$ and $\mathrm{Cr}$, with high positive loadings ( 0.929 and 0.877 , respectively), thus suggesting the natural origin for those two metals. Moderate positive loadings were also found for $\mathrm{Ni}(0.435)$ and $\mathrm{V}(0.575)$, which might indicate that those metals originated from both natural (PC2) and anthropogenic sources (PC1).

PC3 accounted for $10.92 \%$ of the total variance and exhibited moderate positive loadings for $\mathrm{Cu}(0.583)$ and $\mathrm{Zn}(0.407)$ and moderate negative loadings for TOC ($0.420)$ and $\mathrm{Hg}(-0.418)$ (Table 5). This result might indicate different pollution sources for $\mathrm{Cu}$ and $\mathrm{Zn}$ other than the common sources for most heavy metals determined from PC1.

Heavy metal contamination of surface sediments (pollution indices)

EF showed values ranging from 1.2-1.7 (Cr), 1.0-1.9 (Ni), 0.9-4.4 (Cu), 1.1-3.0 (Zn), 2.0-6.6 (As), 0.9-1.6 (V), 1.6-3.7 (Pb), and 0.7-5.3 (Hg). Arsenic showed the 


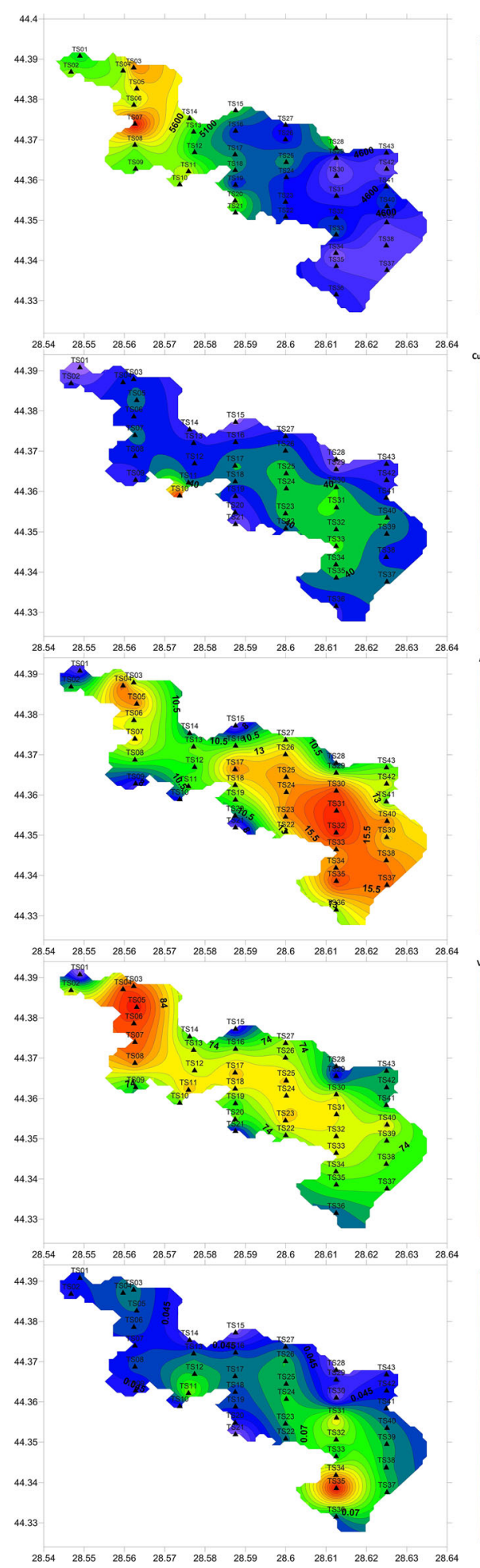

Fig. 3 Metal distribution in the surface sediments of Tasaul Lake

highest mean EF (4.4 \pm 1.3$)$, with ca. $35 \%$ of values between 5 and 10 (most of them in the south of the lake)


$\begin{array}{lllllllllll}28.54 & 28.55 & 28.56 & 28.57 & 28.58 & 28.59 & 28.6 & 28.61 & 28.62 & 28.63 & 28.64\end{array}$

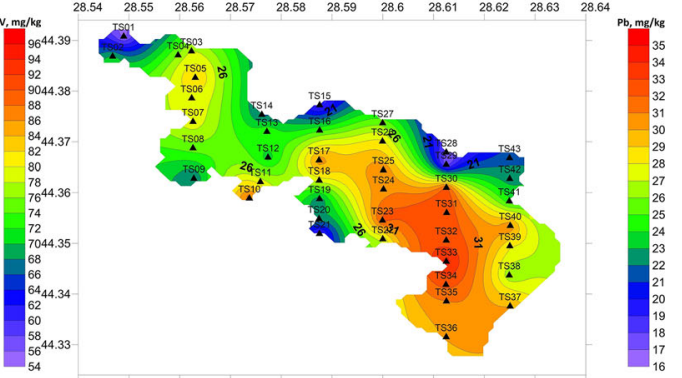

$\begin{array}{lllllllllll}28.54 & 28.55 & 28.56 & 28.57 & 28.58 & 28.59 & 28.6 & 28.61 & 28.62 & 28.63 & 28.64\end{array}$

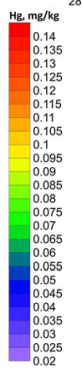

\section{:}




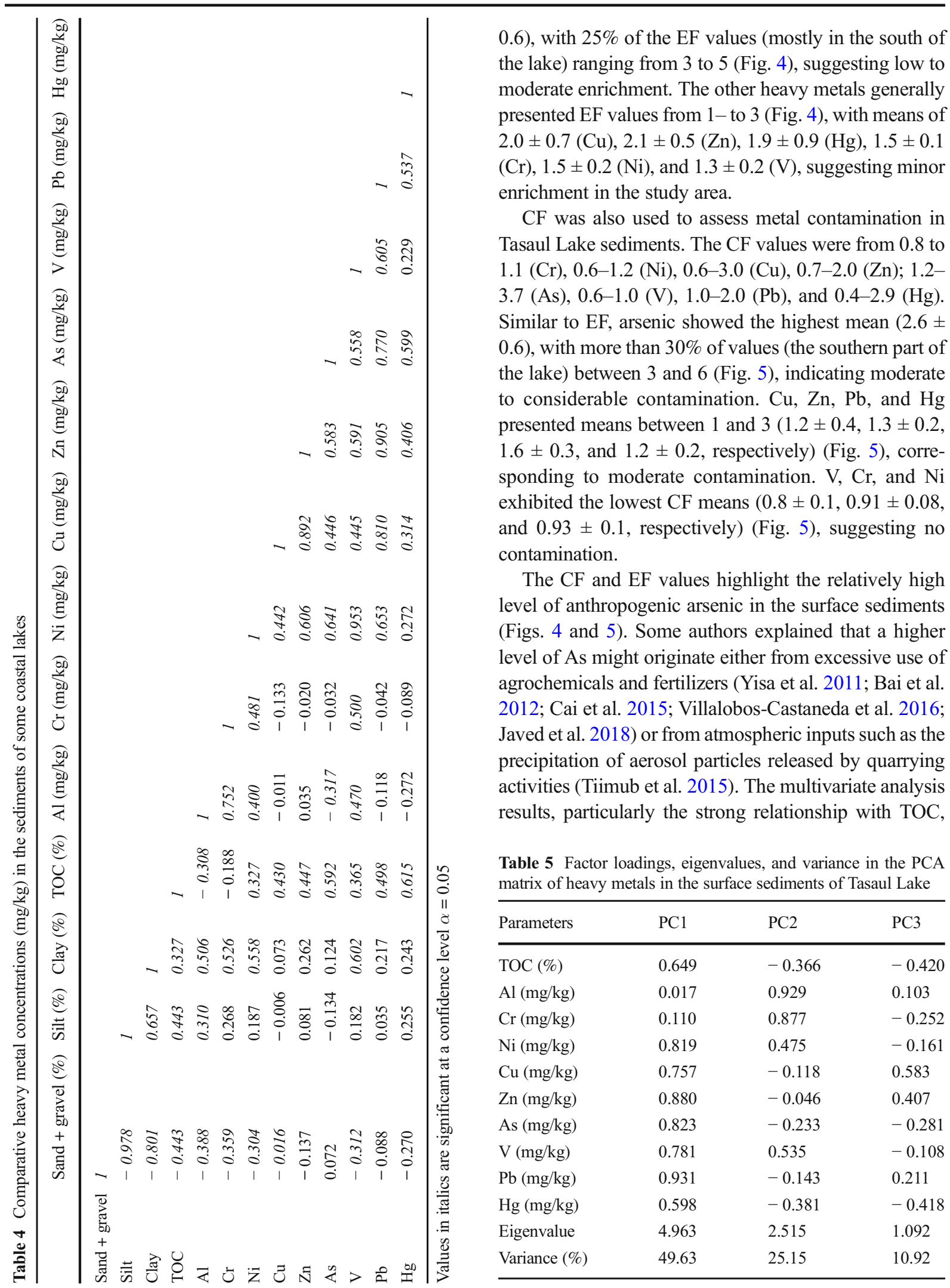



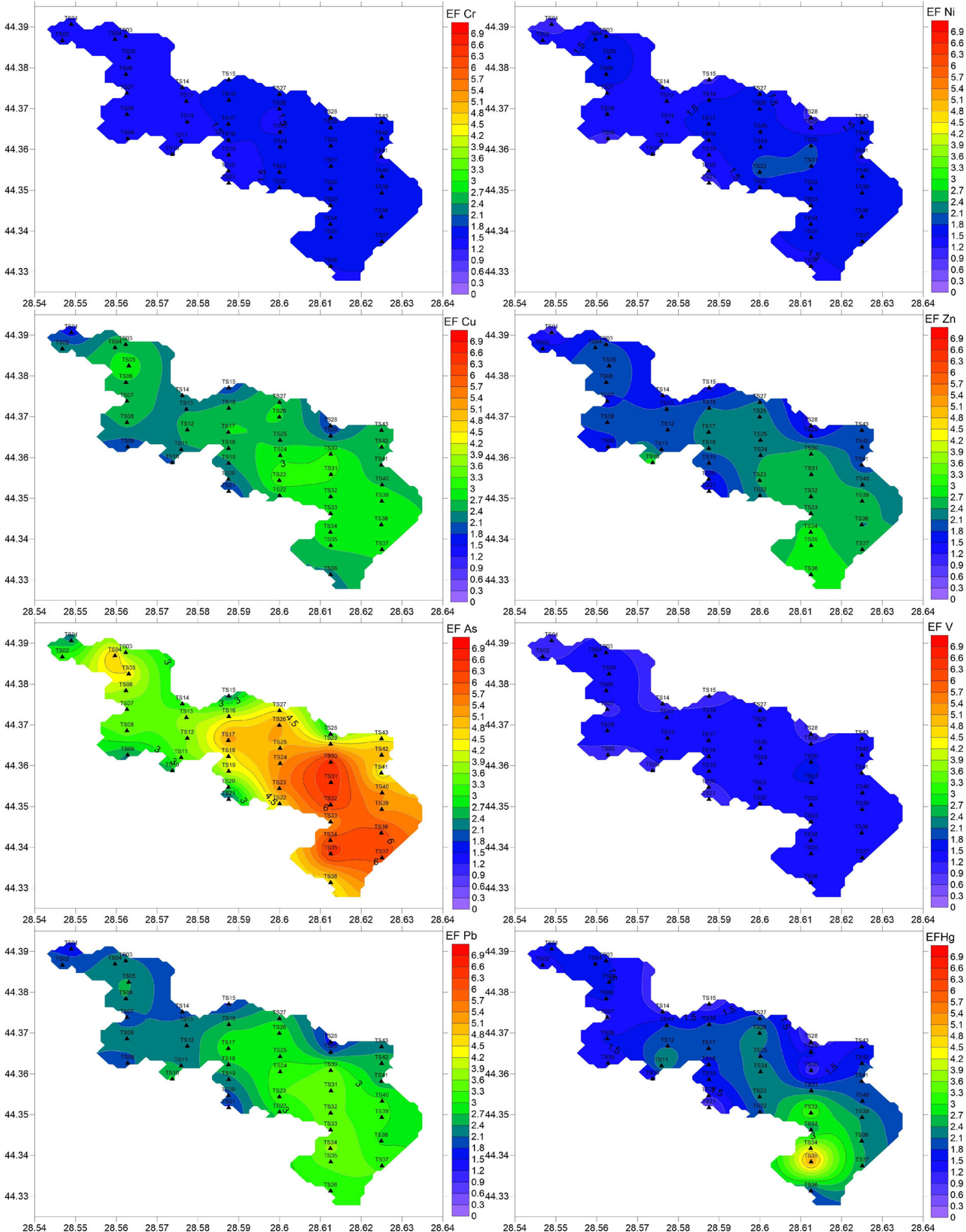

Fig. 4 Spatial distribution of EFs in Tasaul Lake 

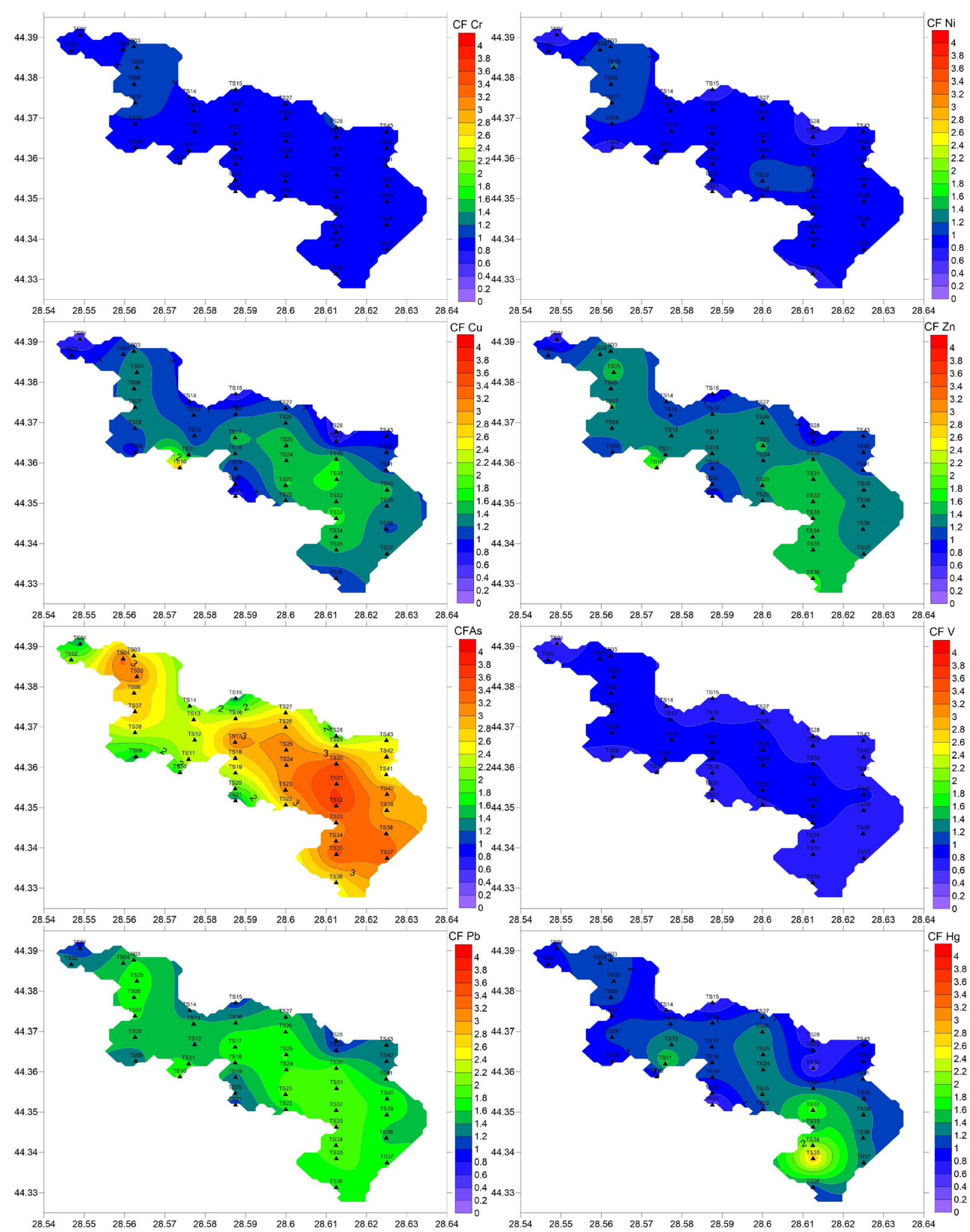

Fig. 5 Spatial distribution of CFs in Tasaul Lake 
suggest a terrestrial source; thus, the high arsenic contamination of surface sediments might be attributed mainly to agricultural runoff.

The second-ranked heavy metal in terms of pollution level in Tasaul Lake sediments was $\mathrm{Pb}$. According to the PCA and correlation matrix, $\mathrm{Pb}$ contamination was primarily attributed to anthropogenic sources, such as leaded gasoline, municipal runoff, and atmospheric deposition (Mukai et al. 1994; Sheela et al. 2012; Mohiuddin et al. 2012). Higher CF and EF values were found in the southeastern part of the lake, which is more strongly impacted by the untreated/poorly treated domestic discharges (from the Navodari city area), urban runoff, vehicle exhaust (car traffic is more intense in Navodari and the surrounding area), and most likely emissions released by the petrochemical plant (Cai et al. 2015; Cao et al. 2020). However, the significant positive correlation between $\mathrm{TOC}$ and $\mathrm{Pb}$ (Table 3) suggests that untreated/poorly treated wastewater and urban runoff are the main pollution sources. The considerable reduction in the use of leaded petrol has contributed to the decrease in the atmospheric input of $\mathrm{Pb}$ (Islam et al. 2015; Kuriata-Potasznik et al. 2016).

The strong relationships between $\mathrm{Cu}, \mathrm{Zn}$, and $\mathrm{Pb}$ (Table 3) suggest quite similar pollution sources. $\mathrm{Cu}$ and $\mathrm{Zn}$ might originate from agricultural runoff and industrial and domestic wastewater as terrestrial sources (Njogu et al. 2011; Sheela et al. 2012; Zeng and Wu 2013; Villalobos-Castaneda et al. 2016; Spagnoli and Andresini 2018), as well as quarrying activities (Etim and Adie 2012; Tiimub et al. 2015). The highest CFs and $\mathrm{EFs}$ for $\mathrm{Cu}$ (3.0 and 4.4, respectively) and $\mathrm{Zn}(2.0$ and 3.0, respectively) were found at station TS10 in the southwest of the lake (Figs. 4 and 5). It is assumed that the pollution at this site is mainly related to quarrying activities (Etim and Adie 2012), but also to agricultural runoff, as $\mathrm{Cu}$ and $\mathrm{Zn}$ are used in fungicides and fertilizers (Momtaz 2002). However, Zn also showed relatively high pollution indices $(\mathrm{CF}=1.5-1.6, \mathrm{EF}=2.8$ 2.9) also in the southeast, in the proximity of the Navodari area (mainly due to urban runoff), while $\mathrm{Cu}$ showed higher values either in the south or in the east of the lake (Figs. 4 and 5), most likely due to agricultural runoff and domestic wastewater discharges and municipal runoff.

Mercury might enter the lake via untreated/poorly treated domestic wastewater discharges (Cai et al. 2015), through the precipitation of aerosol particles released from petrochemical industrial activities (Atoufi and Lampert
2002; Shakhova et al. 2016) and/or vehicle exhaust (Cai et al. 2015). Considering the very strong relationship with TOC (Table 3), the main source of $\mathrm{Hg}$ in the lake seems to be wastewater discharge. The spatial distribution of EFs and CFs (Figs. 4 and 5) showed the highest Hg pollution in the proximity of Navodari city (southeast of the lake) and seems to be related to the expansion of urbanization in the area and the poor domestic wastewater treatment system. However, the CFs and EFs indicate that the overall level of $\mathrm{Hg}$ pollution in Tasaul Lake sediments is relatively low (Figs. 4 and 5).

The lowest EFs and CFs were found for $\mathrm{Cr}, \mathrm{Ni}$, and V. Their spatial distribution, with slightly higher values in the west of the lake (Figs. 4 and 5), might suggest the weathering of greenschist from the Casimcea River watershed, as well as quarry dust resulting from the exploitation of the northwestern quarry, as the main sources. Nickel presented slightly higher CF (1.1) and EF (1.9) values also at stations TS23 and TS30, most likely in connection with agricultural runoff and quarrying activities in northeastern part of the lake.

PLI was used to assess the spatial variability in pollution intensity. Its values ranged from 0.8 to 1.5 , more than $85 \%$ of the values being $>1$, suggesting that heavy metal pollution exists in the surface sediments of Tasaul Lake. The greatest PLIs were found in the south and southeast of the lake (stations TS35, TS34, TS33, and TS32) (Fig. 6), most likely due to the proximity to Navodari city and the petrochemical plant, as well as agricultural activities, while the smallest PLI was measured in one of the gulfs of the eastern part of the lake (station TS21). High PLIs were also observed in the west of the lake (stations TS03, TS05, and TS07) (Fig. 6), which might be related to discharges from the Casimcea and the small river watersheds, as well as quarrying activities.

Hierarchical cluster analysis was applied to datasets of pollution indices (CFs and EFs) to group similar sampling sites (spatial variability). The HCA results were rendered as a dendrogram (Fig. 7), where all the sampling stations were clustered into four statistically significant groups.

The first group consists of stations generally located very close to the lake banks (TS01, TS02, TS09, TS14, TS15, TS20, TS21, and TS28) and showed the lowest PLIs (from 0.8 to 1.0 , with an average value of 0.89 ). Those stations are characterized either by relatively high percentages of sand fraction $(>15 \%)$ or lower TOC $(<$ $1 \%$ ), thus explaining the low accumulation of heavy metals in sediments. 
Fig. 6 Spatial distribution of PLI in Tasaul Lake

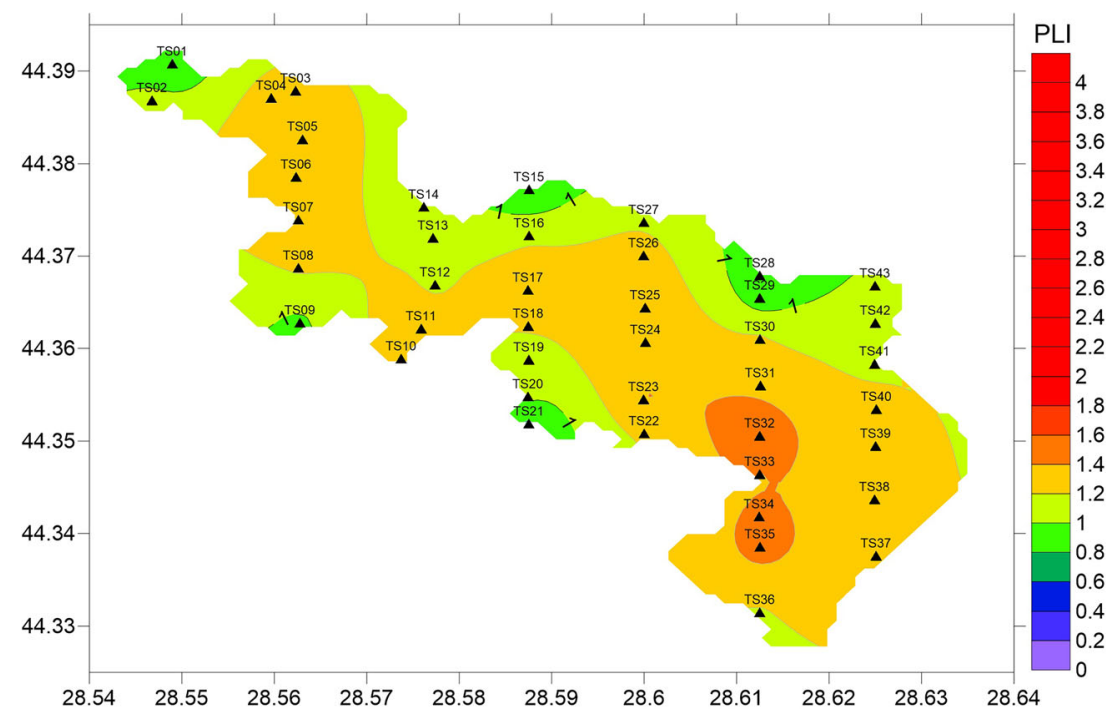

The second group includes 19 stations (PLIs from 0.9 to 1.4 , with an average of 1.19) located mostly in the western part of the lake. The highest PLIs within this group were observed at the stations located in the area of influence of the lake's tributaries (stations TS03, TS04, TS05, TS06, TS07, and TS08). These stations are characterized by higher percentages of clay $(>20 \%)$ and TOC (>2\%), explaining the higher accumulation of heavy metals in sediments. The group also includes the stations located in the northeastern edge of the lake (TS41, TS42, and TS43), very close to the Luminita quarry.

Generally, the second group is impacted by agricultural runoff from the surrounding fields, the Casimcea River and other small temporary river discharges (including agricultural runoff within their watersheds and domestic wastewater discharges), as well as quarrying activities (especially in the northeast of the lake).

The third group consists only of one station, TS10, with a relatively high PLI (1.29), mainly owing to high $\mathrm{Cu}, \mathrm{Zn}$, and $\mathrm{Pb}$ concentrations.

The fourth group contains 14 stations located mostly in the eastern and southeastern parts of the lake and shows a mean PLI of 1.35. Generally, those stations are impacted by agricultural runoff, discharges of domestic wastewater from Navodari city and the surrounding area, industrial activity (especially from the petrochemical plant), road traffic, urbanization, etc. The highest contributions to the PLI values come from As, $\mathrm{Pb}, \mathrm{Hg}, \mathrm{Cu}$, and $\mathrm{Zn}$.

\section{Conclusions}

Grain size, $\mathrm{Al}, \mathrm{TOC}$, and heavy metals $(\mathrm{Cr}, \mathrm{Ni}, \mathrm{Cu}$, $\mathrm{Zn}, \mathrm{As}, \mathrm{V}, \mathrm{Pb}$, and $\mathrm{Hg}$ ) were measured in the surface sediments of Tasaul Lake. The mean concentrations of heavy metals were $83.70 \mathrm{mg} / \mathrm{kg}(\mathrm{Cr})$, $42.53 \mathrm{mg} / \mathrm{kg}(\mathrm{Ni}), 34.27 \mathrm{mg} / \mathrm{kg}(\mathrm{Cu}), 84.40 \mathrm{mg} / \mathrm{kg}$ (Zn), $12.49 \mathrm{mg} / \mathrm{kg}$ (As), $76.45 \mathrm{mg} / \mathrm{kg}$ (V), 26.30 $\mathrm{mg} / \mathrm{kg}(\mathrm{Pb})$, and $0.06 \mathrm{mg} / \mathrm{kg}(\mathrm{Hg}) . \mathrm{As}, \mathrm{Pb}$, and $\mathrm{Hg}$ exhibited the highest concentrations in the south and southeast of the lake (mostly affected by urbanization and industry). $\mathrm{Cu}$ and $\mathrm{Zn}$ showed maxima in the southwest of the lake, while $\mathrm{Cr}, \mathrm{Ni}$, and $\mathrm{V}$ showed maxima in the western part.

According to the multivariate statistical analyses, $\mathrm{Cr}$ predominantly originated from lithogenic components naturally weathered from the surrounding land, while $\mathrm{As}, \mathrm{Cu}, \mathrm{Zn}, \mathrm{Pb}$, and $\mathrm{Hg}$ contamination was related to human activities. Ni and $\mathrm{V}$ showed both lithogenic and anthropogenic sources. The most important anthropogenic sources were fertilizers and pesticides from agricultural runoff ( $\mathrm{As}, \mathrm{Cu}, \mathrm{Zn}$, and $\mathrm{Pb}$ ), industrial and domestic sewage $(\mathrm{Cu}, \mathrm{Zn}, \mathrm{Pb}$, and $\mathrm{Hg})$, and quarry dust $(\mathrm{Cu}, \mathrm{Zn}, \mathrm{Ni}$, and $\mathrm{V})$.

The heavy metal pollution in Tasaul Lake was investigated based on the following indices: EF (enrichment factor), CF (contamination factor), and PLI (pollution index load). The results indicate that the enrichment of metals in surface sediments is dominated by $\mathrm{As}$, followed by $\mathrm{Pb}$. The other investigated heavy metals showed minor enrichment. The highest 
Fig. 7 Dendrogram showing clustering of sampling stations

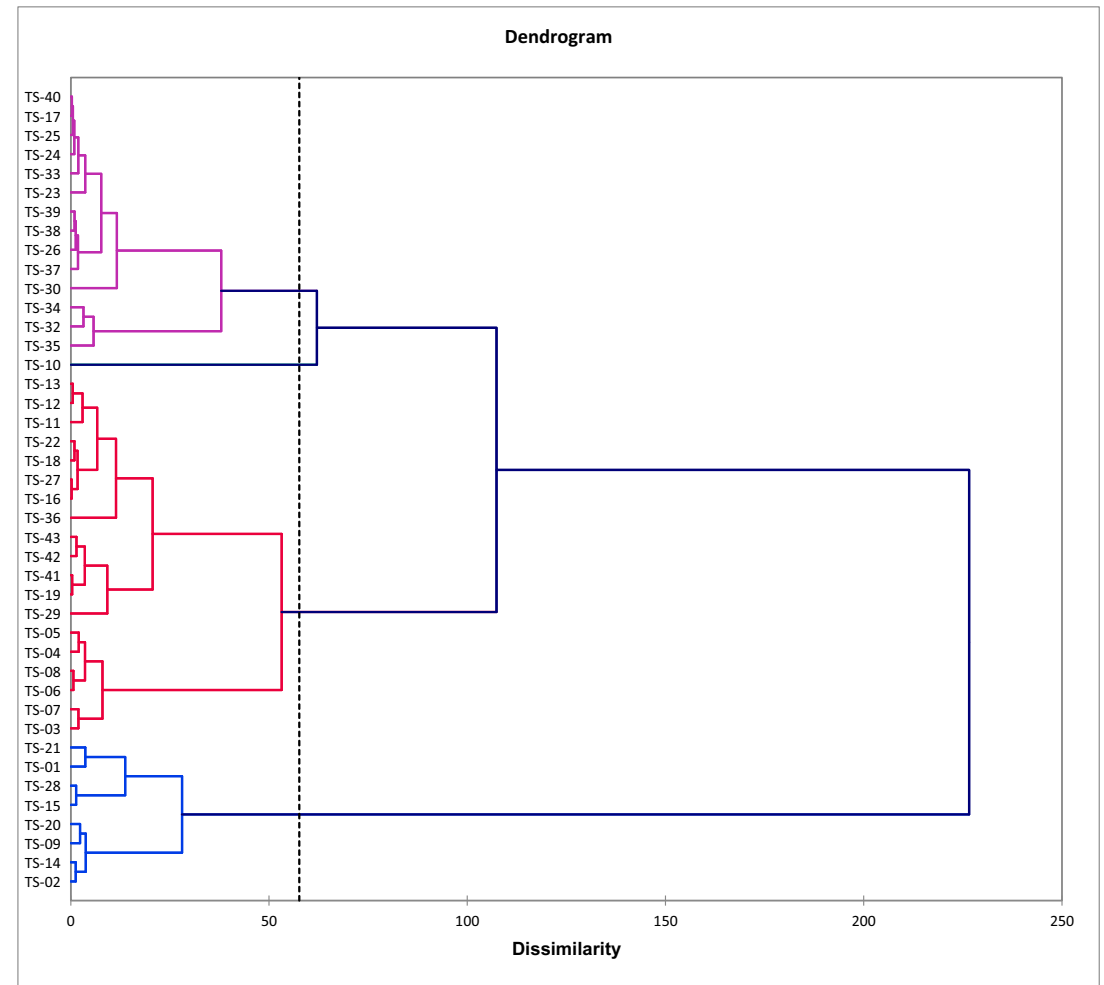

$\mathrm{CF}$ was also determined for As (moderate to considerable contamination), followed by $\mathrm{Pb}, \mathrm{Cu}$, and $\mathrm{Zn}$ (moderate contamination), while the lowest CFs, suggesting no contamination, were observed for $\mathrm{Ni}, \mathrm{Cr}$, and $\mathrm{V}$.

Most PLI values were greater than 1 , suggesting that pollution exists in the surface sediments of Tasaul Lake. According to the PLI spatial mapping and HCA analyses, the most polluted sites in the lake were in the east and southeast of the lake (due to urbanization, the petrochemical industry and agriculture), as well as in the western part, which is impacted by the tributary discharges and quarrying activities.

Funding The present study has been supported by the Ministry of Education and Research (Romania) within the framework of the project PN 19200402 Geological, geochemical, and sedimentological research to assess the influence of natural and anthropogenic factors on the water quality, benthic fauna, and sediment distribution in coastal lakes, in order to sustainably manage their natural resources, as well as the Project Research of Excellence FLUVIMAR no. 8PFE/16.10.2018Data availabilityThe datasets generated during and/ or analyzed during the current study are available from the corresponding author (DV) on reasonable request.

\section{Compliance with ethical standards}

Conflict of interest The authors declare that they have no conflict of interest.
Code availability Not applicable.

Open Access This article is licensed under a Creative Commons Attribution 4.0 International License, which permits use, sharing, adaptation, distribution and reproduction in any medium or format, as long as you give appropriate credit to the original author(s) and the source, provide a link to the Creative Commons licence, and indicate if changes were made. The images or other third party material in this article are included in the article's Creative Commons licence, unless indicated otherwise in a credit line to the material. If material is not included in the article's Creative Commons licence and your intended use is not permitted by statutory regulation or exceeds the permitted use, you will need to obtain permission directly from the copyright holder. To view a copy of this licence, visit http://creativecommons.org/licenses/by/4.0/.

\section{References}

Acevedo-Figueroa, D., Jiménez, B. D., \& Rodríguez-Sierra, C. J. (2006). Trace metals in sediments of two estuarine lagoons from Puerto Rico. Environmental Pollution, 141, 336-342.

Addinsoft. (2020). XLSTAT statistical and data analysis solution. New York, USA. https://www.xlstat.com

Alexandrov, M. L., \& Bloesch, J. (2009). Eutrophication of Lake Tasaul, Romania-proposals for rehabilitation. Environmental Science and Pollution Research, 16, 42-45. 
Alexandrov, M. L., Cernisencu, I., \& Bloesch, J. (2008). History and concepts of sustainable fishery in Taşaul Lake, Romania. Geo-Eco-Marina, 14, 61-71.

Aloupi, M., \& Angelidis, M. O. (2001). Geochemistry of natural and anthropogenic metals in the coastal sediments of the island of Lesvos, Aegaen Sea. Environmental Pollution, 113, 211-219.

Alvisi, F., \& Dinelli, E. (2002). Evolution of sediment composition of the coastal Lake San Puoto (Latium, Italy) in the last two centuries. Journal of Limnology., 61(1), 15-26.

Atici, T., Ahiska, S., Altindag, A., \& Aydin, D. (2008). Ecological effects of some heavy metals $(\mathrm{Cd}, \mathrm{Pb}, \mathrm{Hg}, \mathrm{Cr})$ pollution of phytoplanktonic algae and zooplanktonic organisms in Sar' yyar Dam Reservoir in Turkey. African Journal of Biotechnology, 7(12), 1972-1977.

Atoufi, D. H., \& Lampert, D. J. (2002). Impacts of oil and gas production on contaminant levels in sediments. Current Pollution Reports, 6, 43-53.

Bai, J., Xiao, R., Zhang, K., Gao, H. (2012). Arsenic and heavy metal pollution in wetland soils from tidal freshwater and salt marshes before and after the flow-sediment regulation regime in the Yellow River Delta, China. Journal of Hydrology, 450-451, 244-253, 450-451

Benson, N. U., Asuquo, F. E., Williams, A. B., Essien, J. P., Ekong, C. I., Akpabio, O., \& Olajire, A. A. (2016). Source evaluation and trace metal contamination in benthic sediments from equatorial ecosystems using multivariate statistical techniques. PloS One, 11(6), 1-19.

Bing, H., Wu, Y., Zhaobin Sun, Z., \& Yao, S. (2011). Historical trends of heavy metal contamination and their sources in lacustrine sediment from Xijiu Lake, Taihu Lake Catchment, China. Journal of Environmental Sciences, 23(10), 1671-1678.

Bloesch, J., \& Alexandrov, L. (2007). Assessment of anthropogenic impacts on Tasaul Lake, Romania, and ecosystem rehabilitation-The "Tasaul" Project in the Framework of the Swiss-Romanian Research Program ESTROM Environmental Science and Technology in Romania-an overview. Cercetari Marine, 37, 7-16.

Breier, A. (1976). The lakes in the Romanian littoral area. A hydrogeographic study. Bucharest: Editura Academiei Republicii Socialiste Romania (in Romanian).

Bucur Arpenti, M., Negreanu-Pirjol, T., Ehlinger, T. J., Paraschiv, G.-M., \& Tofan, L. (2014). Heavy metal content analysis of Siutghiol Lake water and sediment. Revista de Chimie, 65(9), 1108-1113.

Cai, L., Xu, Z., Bao, P., He, M., Dou, L., Chen, L., Zhou, Y., \& Zhu, Y. G. (2015). Multivariate and geostatistical analyses of the spatial distribution and source of arsenic and heavy metals in the agricultural soils in Shunde, Southeast China. Journal of Geochemical Exploration, 148, 189-195.

Cao, L., Lin, C., Gao, Y., Sun, C., Xu, L., Zheng, L., \& Zhang, L. (2020). Health risk assessment of trace elements exposure through the soil plant (maize)-human contamination pathway near a petrochemical industry complex, Northeast China. Environmental Pollution, 263(Pt. A), 114414.

Caraivan, G., Secrieru, D., Fulga, C., Paun, F., \& Opreanu, P. (2011). Tabacariei Lake - a model of urban pollution. GeoEco-Marina, 17, 81-94.
Cernisencu, I., Alexandrov, L., Orac, O., Bloesch, J., Tofan, L., Arhire, D., \& Paris, P. (2007). Tasaul Lake fisheries characteristics and research. Cercetari Marine, 37, 126-142.

Dou, Y., Li, J., Zhao, J., Hu, B., \& Yang, S. (2013). Distribution, enrichment and source of heavy metals in surface sediments of the eastern Beibu Bay, South China Sea. Marine Pollution Bulletin, 67, 137-145.

El-Amier, Y. A., Elnaggar, A. A., \& El-Alfy, M. A. (2017). Evaluation and mapping spatial distribution of bottom sediment heavy metal contamination in Burullus Lake. Egypt. Egyptian Journal of Basic and Applied Sciences, 4(1), 5566.

Etim, E. U., \& Adie, G. A. (2012). Assessment of toxic heavy metal loading in topsoil samples within the vicinity of a limestone quarry in South Western Nigeria. African Journal of Environmental Science and Technology, 6(8), 322-330.

Gaudette, H. E., Flight, W. R., Toner, L., \& Folger, W. (1974). An inexpensive titration method for the determination of organic carbon in recent sediments. Journal of Sedimentary Petrology, 44, 249-253.

Hakanson, L. (1980). Ecological risk index for aquatic pollution control. A sedimentological approach. Water Research, 14, 975-1001.

Islam, M. S., Ahmed, M. C., Raknuzzaman, M., Al-Mamun, M. H., \& Islam, M. K. (2015). Heavy metal pollution in surface water and sediment: a preliminary assessment of an urban river in a developing country. Ecological Indicators, 48, 282-291.

Javed, T., Ahmad, N., \& Mashiatullah, A. (2018). Heavy metals contamination and ecological risk assessment in surface sediments of Namal Lake, Pakistan. Poish Journal of Environmental Studies, 27(2), 675-688.

Jiang, X., Wang, W., Wang, S., Zhang, B., \& Hu, J. (2012). Initial identification of heavy metals contamination in Taihu Lake, a eutrophic lake in China. Journal of Environmental Sciences, 24(9), 1539-1548.

Kükrer, S., Ahmet, E., Șeref, K., Özender, B., Taylan, A., \& Erdal, Ö. (2020). Ecological risk assessment of surface sediments of Çardak Lagoon along a human disturbance gradient. Environmental Monitoring and Assessement, 192, 359.

Kuriata-Potasznik, A., Szymczyk, S., Skwierawski, A., GlinskaLewczuk, K., \& Cymes, I. (2016). Heavy metal contamination in the surface layer of bottom sediments in a flowthrough lake: a case study of Lake Symsar in Northern Poland. Water, 8, 358-373.

Liaghati, T., Preda, M., \& Cox, M. (2003). Heavy metal distribution and controlling factors within coastal plain sediments Bells Creek catchment southeast Queensland, Australia. Environment International, 29, 953-948.

Maina, C. W., Sang, J. K., Raude, J. M., \& Mutua, B. M. (2019). Geochronological and spatial distribution of heavy metal contamination in sediment from Lake Naivasha, Kenya. Journal of Radiation Research and Applied Sciences, 12(1), 37-54.

Mateescu, R., Vasiliu, D., Teodorescu, D., \& Alexandrov, M. L. (2007). Nutrient input of Casimcea River and the main tributaries into Tasaul Lake. Cercetari Marine, 37, 17-31.

Mohiuddin, K. M., Otomo, K., Ogawa, Y., \& Shikazono, N. (2012). Seasonal and spatial distribution of trace elements in the water and sediments of the Tsurumi River in Japan. Environmental Monitoring and Assessment, 184, 265-279. 
Momtaz, S. (2002). Environmental impact assessment in Bangladesh: a critical review. Environmental Impact Assessment, 22(2), 163-179.

Mukai, H., Tanaka, A., Fujii, T., \& Nakao, M. (1994). Lead isotope ratios of airborne particulate matter as tracers of long-range transport of air pollutants around Japan. Journal of Geophysical Research, 99, 3717-3726.

Njogu, P. M., Keriko, J. M., Wanjau, R. N., \& Kitetu, J. J. (2011). Distribution of heavy metals in various lake matrices; water, soil, fish and sediments: a case study of the Lake Naivasha basin, Kenya. Journal of Agriculture, Science and Technology, 13, 91-106.

O'Reilly-Wiese, S. B., Bubb, J. M., \& Lester, J. N. (1995). The significance of sediment metal concentrations in two eroding Essex salt marshes. Marine Pollution Bulletin, 30(3), 190199.

Oros, A. (2007). Heavy metals in water and sediments of Tasaul Lake (2005-2006). Cercetari Marine, 37, 66-74.

Popescu, D., Caraivan, G., (2002-2003). Lake Taşaul site evolution during the Late Quaternary. Pontica, 35-36, 53-59 (In Romanian)

Rippey, B., Rose, N., Yang, H., Harrad, S., Robson, M., \& Travers, S. (2008). An assessment of toxicity in profundal lake sediment due to deposition of heavy metals and persistent organic pollutants from the atmosphere. Environment International, 34(3), 345-356.

Rosioru, D. M., Bossard, P., Steiner, D., Vasiliu, D., Alexandrov, L., \& Patrascu, V. (2008). Cercetari Marine, 38, 73-79.

Rudnic, R. L., \& Gao, S. (2003). The composition of the continental crust. In R. L. Rudnick, H. D. Holland, \& K. K. Turekian (Eds.), Treatise on Geochemistry - The Crust (pp. 1-64). Oxford: Elsevier.

Sakan, S. M., Djordjevic, D. S., Manojlovic, D. D., \& Polic, P. S. (2009). Assessment of heavy metal pollutants accumulation in the Tisza river sediments. Journal of Environmental Management, 90, 3382-3390.

Schropp, S. J., Lewis, F. G., Windom, H. L., Ryan, J. D., Calder, F. D., \& Burney, L. C. (1990). Interpretation of metal concentrations in estuarine sediments of Florida using aluminum as a reference element. Estuaries, 13(3), 227-235.

Shakhova, T. S., Talovskaya, A. V., Yazikov, E. G., Filimonenko, E. A., \& Lyapina, E. E. (2016). Assessment of mercury pollution in the vicinity of petrochemical complex in winter-by the example of pavlodar, Kazakhstan. Bulletin of the Tomsk Polytechnic University Geo Assets Engineering, 327(12), 16-25.

Sheela, A. M., Letha, J., Joseph, S., \& Thomas, J. (2012). Assessment of heavy metal contamination in coastal lake sediments associated with urbanization: Southern Kerala, India. Lakes \& Reservoirs: Research and Management, 17, 97-112.

Shepard, F. P. (1954). Journal of Sedimentary Research, 24(3), $151-158$

Spagnoli, F., \& Andresini, A. (2018). Biogeochemistry and sedimentology of Lago di Lesina (Italy). Science of the Total Environment, 643, 868-883.
Tiimub, B. M., Sarkodie, P. A., Monney, I., \& Maxwell, O. (2015). Heavy metal contamination of soil by quarry dust at Asonomaso in the Ashanti Region of Ghana. Chemistry and Materials Research, 7(5), 42-50.

Tomlinson, D. L., Wilson, J. G., Harris, C. R., \& Jeffrey, D. W. (1980). Problems in the assessment of heavy-metal levels in estuaries and the formation of a pollution index. Helgoländer Meeresuntersuchungen, 33, 566-575.

Trojanowski, J., Trojanowska, C., \& Jańczak, C. (2007). Heavy metals migration in the system: near-bottom water-interstitial water-bottom sediment in Gardno Lake. Baltic Coastal Zone, $11,83-101$.

Varol, M. (2011). Assessment of heavy metal contamination in sediments of the Tigris River (Turkey) using pollution indices and multivariate statistical techniques. Journal of Hazardous Materials, 195, 355-364.

Vasiliu, D., Lazar, L., Alexandrov, L., Smocov, V., Cociasu, A., \& Rosiouru, D. (2007). The influence of the main pollution sources on Tasaul Lake's physical-chemical parameters. Cercetari Marine, 37, 39-50.

Villalobos-Castaneda, B., Cortes-Martinez, R., Segovia, N., Buenrostro-Delgado, O., Morton-Berme, O., \& AlfaroCuevas-Villanueva, R. (2016). Distribution and enrichment of trace metals and arsenic at the upper layer of sediments from Lerma River in La Piedad Mexico: case history. Environmental Earth Sciences, 75, 1490-1502.

Wang, Y., Hu, J., Xiong, K., Huang, X., \& Duan, S. (2012). Distribution of heavy metals in core sediments from Baihua Lake. Procedia Environmental Sciences, 16, 51-58.

Ward, J. H. (1963). Hierarchical grouping to optimize an objective function. Journal of the American Statistical Association, 58, 238-244.

Wu, B., Wang, G., Wu, J., Fu, Q., \& Liu, C. (2014). Sources of heavy metals in surface sediments and an ecological risk assessment from two adjacent plateau reservoirs. PLoS ONE, 9(7), e102101. https://doi.org/10.1371/journal. pone.0102101.

Yang, Y., Liu, Z., Chen, F., Wu, S., Zhang, L., Kang, M., \& Li, J. (2014). Assessment of trace element contamination in sediment cores from the Pearl River and estuary, South China: geochemical and multivariate analysis approaches. Environmental Monitoring and Assessment, 186, 80898107.

Yisa, J., Jacob, J. O., \& Onoyima, C. C. (2011). Identification of sources of heavy metals pollution in road deposited sediments using multivariate statistical analysis. Journal of Emerging Trends in Engineering and Applied Sciences, 2(4), 658-663.

Zeng, H., \& Wu, J. (2013). Heavy metal pollution of lakes along the mid-lower reaches of the Yangtze River in China: intensity, sources and spatial patterns. International Journal of Environmental Research and Public Health, 10, 793-807.

Publisher's note Springer Nature remains neutral with regard to jurisdictional claims in published maps and institutional affiliations. 